it is probable that the information transcribed from the viral genome in transformed cells is sufficient for only two or three average-size proteins. To determine whether all the cell changes follow the expression of one viral gene, or more than one, will depend on the isolation and study of further viral mutants affecting transformation.

Another major problem concerns the relationship of these various manifestations of transformation to one another and to the initiation of a cell growth cycle. Is increased glycolysis, for example, or altered cell movement, related to initiation of D.N.A. synthesis, and if so is it a cause or a consequence? This may now be investigated by determining the time of appearance of the changes during abortive transformation in mass cultures to see whether they precede or succeed the growth initiation

\section{Conclusion}

Studies on cultured fibroblasts have led us to postulate a form of growth regulation which involves a general extracellular factor, the action of which is affected by very local changes in the topography and perhaps the membrane state of individual cells. If this system operates in a whole organism such as the human body it is likely to be one of a large number of integrated sets of growth-regulation systems, and could be a relatively minor one. Nevertheless, the system deserves our attention, not just because it can be isolated for experimental investigation, but because it is by-passed in cells transformed with carcinogenic viruses. Since they have few genes these viruses cannot perform many operations and so cannot be doing much else even when starting a tumour in an animal. For that reason we may hope that the changes in growth observed in cultured cells may indeed be relevant to real cancer.
REFERENCES

Abercrombie, M., and Heaysman, J. E. (1954). Experimental Cell Research, 6, 293.

Bullough, W. S., and Laurence, E. B. (1960). Proceedings of the Royal Society Series $B, 151,517$.

Bullough, W. S., Laurence, E. B., Iversen, O. H., and Elgjo, K. (1967). Nature, 214, 578.

Bürk, R. R. (1967). In Growth Regulating Substances for Animal Cells in Culture, ed. V. Defendi and M. Stoker, p. 39. Philadelphia, Wistar Institute Press.

Clarke, G. D., Stoker, M. G. P., Ludlow, A., and Thornton, M. (1970). In press.

Dulbecco, R. (1970). In press.

Dulbecco, R., Hartwell, L. H., and Vogt, M. (1965). Proceedings of the National Academy of Sciences of the United States of America, 53, 403. National Academy of Sciences of the United States
Dulbecco, R., and Stoker, M. G. P. (1970). In press.

Dulbecco, R., and Stoker, M. G. P.
Fried, M. (1965). Virology, 25, 669.

Fried, M. (1965). Virology, 25, 669.
Fried, M. (1970). Virology, 40, 605.

Fried, M. (1970). Virology, 40, 605.
Healey, G. M., and Parker, R. C. (1966). Fournal of Cell Biology, 30, 539.
Holley, R. W., and Kiernan, J. A. (1968). Proceedings of the National Academy of Sciences of the United States of America, 60, 300.

Levine, M., Becker, Y., Boone, C. W., and Eagle, H. (1965). Proceeding of the National Academy of Sciences of the United States of America, 53, 350 .

Macpherson, I. (1965). Science, 148, 1731.

Macpherson, I., and Montagnier, L. (1964). Virology, 23, 291.

Macpherson, I., and Stoker, M. (1962). Virology, 16, 147.

Marin, G., and Macpherson, I. (1969). fournal of Virology, 3, 146

Martin, L., and Finn, C. A. (1968). Fournal of Endocrinology, 41, 363.

Martin, L., and Finn, C. A. (1968). Fournal of Endocrin
Stoker, M., and Dulbecco, R. (1969). Nature, 223, 397.

Stoker, M., and Dulbecco, R. (1969)

Stoker, M. (1968). Nature, 218, 234. Fournal of Cancer, 3,683 .

Temin, H. M. (1960). Virology, 10, 182.

Temin, H. M. (1967). Fournal of Cellular Physiology, 69, 377.

Temin, H. M. (1968). International fournal of Cancer, 3, 771 .

Todaro, G. J., and Green, H. (1963). Fournal of Cell Biology, 17, 299.

Todaro, G. J., Lazar, G. K., and Green, H. (1965). Fournal of Cellular and Comparative Physiology, 66, 325.

Todaro, G., Matsuya, Y., Bloom, S., Robbins, A., and Green, H. (1967). In Growth Regulating Substances for Animal Cells in Culture, ed. V. Defendi and M. G. P. Stoker, p. 87. Philadelphia, Wistar Institute Press.

Weil, R., Michel, M. R., and Ruschmann, G. K. (1965). Proceedings of the National Academy of Sciences of the United States of America, 53, 1468. Weiss, M. C., Ephrussi, B., and Scaletta, L. J. (1968). Proceedings of the National Academy of Sciences of the United States of America, 59, 1132. Winocour, E., Kaye, A. M., and Stoller, V. (1965). Virology, 25, 156.

\title{
Fibrin Degradation Products in Pre-eclamptic Toxaemia and Eclampsia
}

\author{
A. H. HENDERSON,* M.B., M.R.C.P. ; D. J. PUGSLEY, † M.B., M.R.C.P. ; D. P. THOMAS, $\ddagger$ M.D., B.SC., D.PHIL.
}

British Medical fournal, 1970, 3, 545-547

\begin{abstract}
Summary: Serum levels of fibrinogen/fibrin degrada$\checkmark$ tion products, measured in African women, were significantly higher in pre-eclamptic toxaemia than in normal pregnancy, and were significantly higher with eclampsia than with toxaemia. These findings are in accord with the hypothesis that eclampsia and toxaemia are associated with disseminated intravascular coagulation, which may be responsible for certain clinical manifestations of these conditions.
\end{abstract}

\section{Introduction}

It has been suggested that disseminated intravascular coagulation is responsible for many of the manifestations of preeclamptic toxaemia and eclampsia (McKay, Merrill, Weiner, Hertig, and Read, 1953; McKay and Corey, 1964). Disseminated intravascular coagulation is characterized by the consumption of platelets, fibrinogen, and blood-clotting factors $\mathrm{V}$ and VIII, leading to a decrease in their circulating levels if

\footnotetext{
* Senior Registrar in Medicine, Royal Devon and Exeter Hospital, Exeter. + Registrar in Medicine, Makerere University College, Kampala, Uganda. ₹ Associate Professor of Medicine, Tufts University School of Medicine Physician-in-charge, Vascular Laboratory, Lemuel Shattuck Hospital,
Boston, Massachusetts.
}

the process is sufficiently acute. There is also an increase in the level of circulating fibrinogen/fibrin degradation products (F.D.P.), produced as a result of secondary, or compensatory, fibrinolysis. Obstructive microangiopathy may follow the formation of intravascular thrombi, with subsequent deposition of fibrin. Red cell fragmentation may also occur, and this has been attributed to mechanical damage sustained as red cells pass through a fibrin mesh in still patent vessels (McKay and Shapiro, 1958; Brain, Dacie, and Hourihane, 1962; McKay, 1964).

The clinical, histological, and haematological changes of eclampsia, and to a lesser extent of toxaemia, show many similarities to other clinical features attributed to disseminated intravascular coagulation (Taub, Rodríguez-Erdmann, and Dameshek, 1964). Thus there are the signs of renal disease which may progress to acute renal failure; convulsions which may occur even in the absence of severe hypertension; and fibrin-like material which has been demonstrated in the endothelium of small blood vessels from many organs in eclampsia and in the kidney in toxaemia (Govan, 1961; Vassalli, Morris, and McCluskey, 1963; McKay, 1964). Red cell fragmentation and thrombocytopenia have been reported in eclampsia, with increased platelet stickiness in toxaemia 
(McKay, 1964; Morris, Vassalli, Beller, and McCluskey, 1964; Brain, Kuah, and Dixon, 1967; Bonnar, Davidson, Pidgeon, McNicol, and Douglas, 1969a). The increased levels of clotting factors and decreased fibrinolysis found in late pregnancy tend to favour fibrin deposition (Astrup, 1956; Biezenski and Moore, 1958; Pechet and Alexander, 1961; Talbert and Langdell, 1964; Nilsson and Kullander, 1967; Wardle and Menon, 1969; Bonnar, McNicol, and Douglas, 1969b).

Documented examples of disseminated intravascular coagulation have been reported in severe pre-eclampsia and eclampsia (Brain et al., 1967; Bonnar et al., 1969b), and several of the reported cases of thrombocytopenic purpura, whose manifestations are those of disseminated intravascular coagulation, have occurred in association with pregnancy (Amorosi and Ultmann, 1966). Whether toxaemia and eclampsia are invariably associated with disseminated intravascular coagulation, however, remains to be established. Since the presence of increased F.D.P. levels is probably the most sensitive index of disseminated intravascular coagulation currently available, F.D.P. levels were measured in an unselected series of women with normal pregnancy, pre-eclamptic toxaemia, and eclampsia.

\section{Methods}

Sera for F.D.P. levels were obtained from 47 African Negro women with normal pregnancy (27), pre-eclamptic toxaemia (15), and eclampsia (5). Thirty-two were pregnant and 15 were postpartum; 25 of the pregnant patients were in the third trimester. All postpartum blood samples were obtained within 24 hours of delivery. For comparison, sera were also obtained from nine non-pregnant African controls and six non-pregnant patients with essential hypertension.

Patients with albuminuria, oedema, and hypertension $(>130 / 90 \mathrm{~mm} . \mathrm{Hg})$ or with albuminuria and hypertension which developed late in pregnancy were considered to have pre-eclamptic toxaemia. Those who in addition experienced one or more convulsions without previous history of epilepsy were considered to have eclampsia. Patients with other serious diseases, such as overt venous thrombosis or sicklecell anaemia, were excluded. Single 5-ml. blood samples were taken from each patient and incubated at $37^{\circ} \mathrm{C}$. for four hours, after which the serum was separated, frozen, and stored. The frozen serum samples were then flown to Boston. Thrombin (Parke-Davis) was added to the thawed serum (10 N.I.H. units $/ \mathrm{ml}$.), which was then incubated for a further two hours at $37^{\circ} \mathrm{C}$. After centrifugation at $1,300 \times \mathrm{g}$. the supernatant serum from all the samples was tested for F.D.P. with the Staphylococcal Clumping Test (Hawiger, Niewiarowski, Gurewich, and Thomas, 1970).

Ten milligrams of bacterial powder (kindly supplied by Dr. J. Hawiger, Vanderbilt University Medical School, Nashville, Tennessee) was suspended in $1 \mathrm{ml}$. of $0.05 \mathrm{M}$ tris buffer, $(p \mathrm{H}$ 7.4), containing $0.01 \%$ bovine albumin (Hyland Laboratories, Los Angeles, California). Freshly prepared suspensions were used within one hour of preparation. $0.1 \mathrm{ml}$. of diluted test material in test-tubes $(10 \times 75 \mathrm{~mm}$.) was mixed with $0.05 \mathrm{ml}$. of bacterial suspension. After the material had been shaken $0.5 \mathrm{ml}$. of tris buffer was added. The tubes were examined for clumping after 30 minutes of incubation at room temperature, with the use of direct light (tubes held just under the rim of a high-intensity lamp) and black background. All samples were read directly against a control in which a buffer was used instead of the tested material. Only tubes with a distinct clump of bacteria were considered positive. Serial dilutions of test serum in tris-saline buffer were prepared for determination of the clumping titre. Results were expressed in $\mu \mathrm{g}$. of fibrinogen equivalent $/ \mathrm{ml}$. ( $\mu \mathrm{g} . / \mathrm{ml}$.) with purified human fibrinogen (Kabi, Stockholm, Sweden) as a reference standard. The statistical significance of differences between groups was calculated with Student's $t$ test, and the results are given as the mean \pm standard error.

\section{Results}

F.D.P. levels in the first and second trimesters of normal pregnancy were similar to those found in normal non-pregnant African women, and fell within the previously established normal range for this laboratory $(1-2 \mu \mathrm{g} . / \mathrm{ml}$.) (see Table). F.D.P. levels were significantly higher $(P=0.02)$ in the third trimester of normal pregnancy $(4.8 \mu \mathrm{g} . / \mathrm{ml}$.$) than in$ the first two trimesters, and remained similarly raised immediately postpartum ( $<24$ hours). F.D.P. levels in pre-eclamptic toxaemia, both before the onset of labour $(21.4 \mu \mathrm{g} . / \mathrm{ml}$.) and postpartum $(30.4 \mu \mathrm{g} . / \mathrm{ml}$.) were significantly higher $(\mathrm{P}<0.01)$ than in the comparable stages of normal pregnancy. In eclampsia postpartum F.D.P. levels were strikingly raised, to values significantly greater than in toxaemia $(P<0.01)$.

In non-pregnant patients with essential hypertension F.D.P. levels were similar to those found in normal controls, while in two patients with essential hypertension in the third trimester of pregnancy these levels did not differ significantly from those found in the third trimester of normal pregnancy, and were much lower than those characteristic of toxaemia (see Table).

\section{Discussion}

Our findings in patients with normal pregnancy confirm previous reports that F.D.P. levels are slightly raised in late normal pregnancy (Woodfield, Cole, Allan, and Cash, 1968) and postpartum (Bonnar et al., 1969a). F.D.P. levels in toxaemia have not previously been reported, and are significantly higher than in normal pregnancy, both before the onset of labour and postpartum; in eclampsia F.D.P. were increased further to very high levels. A pronounced rise in F.D.P. levels was described in a previous report of two patients with eclampsia (Bonnar et al., 1969a). In these previous studies F.D.P. levels in pregnancy were measured by the tanned red cell haemagglutination immunoassay (Merskey, Kleiner, and Johnson, 1966). In the present investigation F.D.P. were measured by a staphylococcal clumping assay, which has been shown to provide a highly sensitive measure of F.D.P. ( $>0.5 \mu \mathrm{g} . / \mathrm{ml}$.), particularly for "early" breakdown products (Hawiger et al., 1970). Samples from normal African women, collected and transported by the methods described, showed F.D.P. levels within the normal range for this laboratory.

Serum levels of F.D.P. provide a sensitive measure of increased fibrinolysis, either primary or secondary. Plasma fibrinolytic activity is reduced in late normal pregnancy, toxaemia, and eclampsia (Morris et al., 1964; Bonnar et al., 1969a; Wardle and Menon, 1969). The present findings indicate that the overall level of F.D.P. is significantly increased in toxaemia and strikingly increased in eclampsia

Mean Levels ( \pm S.E. of Mean) of F.D.P. ( $\mu \mathrm{g} . / \mathrm{ml}$ ) $)$ in Controls, Normal Pregnancy, Essential Hypertension, Toxaemia, and Eclampsia

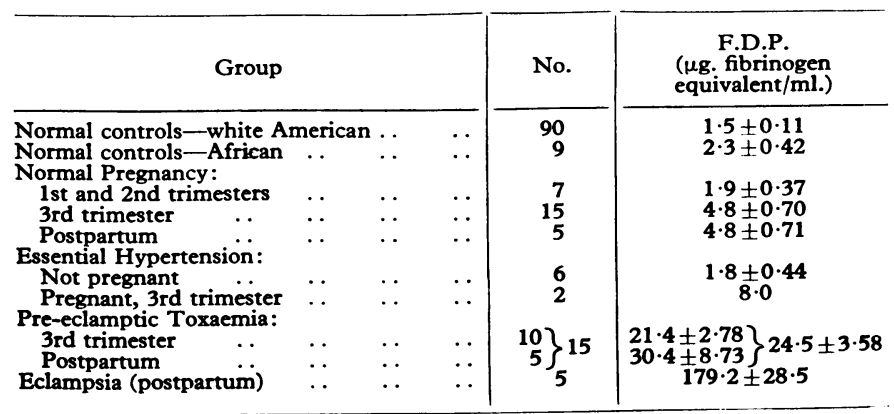


(see Table). On the basis of the present data it is not known whether the raised F.D.P. titres are due to fibrinogen or fibrin breakdown products, since the staphylococcal clumping assay is sensitive to both. Unfortunately it proved impracticable to obtain other supporting data which might have allowed us to distinguish between the two types of F.D.P. Very probably, however, raised F.D.P. titres in toxaemia and eclampsia are due to secondary fibrinolysis and that mainly fibrin degradation products are being measured. Primary fibrinolysis is a relatively rare condition; moreover, the F.D.P. titres found in eclampsia were very similar to those found with the staphylococcal clumping assay in typical acute disseminated intravascular coagulation (Thomas, Niewiarowski, Meyers, Bloch, and Colman, 1970).

Our findings support the hypothesis that disseminated intravascular coagulation is occurring in eclampsia and is responsible for many of the clinical manifestations by causing widespread occlusion of the small vessels in the kidneys, brain, and other organs. A similar but milder process, where fibrin deposition is limited to the renal microcirculation, may occur in toxaemia (McKay et al., 1953; McKay and Corey, 1964). The possibility that much of the implied increase in fibrin formation takes place in the uterine and placental vessels (Woodfield et al., 1968) cannot be excluded. It has been postulated that disseminated intravascular coagulation could be triggered by the release of thromboplastin from the placenta (McKay and Corey, 1964). A similar mechanism has also been proposed to account for the depletion of clotting factors and the rise in F.D.P. after abruptio placentae and fetal death-in-utero (Bonnar et al., 1969a). The differences between the various clinical syndromes associated with disseminated intravascular coagulation in pregnancy may in part be attributed to the quantitative differences in the rates and sites of fibrin formation and subsequent lysis.
We thank Mr. J. Nshaho, Mrs. Elizabeth Hutchinson, and Mrs. Lynn Smith for their invaluable assistance. We also thank Professor R. R. Trussel and Professor A. G. Shaper for their encouragement and advice. This work was supported by a grant from the United States Public Health Service (HE-09203) and also by a grant from Roche Products Ltd.

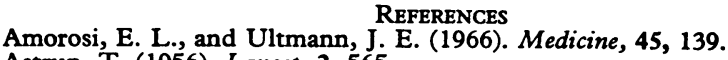

Astrup, T. (1956). Lancet, 2, 565.

Biezenski, J. J., and Moore, H. C. (1958). Fournal of Clinical Pathology, 11, 306.

Bonnar, J., Davidson, J. F., Pidgeon, C. F., McNicol, G. P., and Douglas, A. S. (1969a). British Medical fournal, 3, 137.

Bonnar, J., McNicol, G. P., and Douglas, A. S. (1969b). British Medical Fournal, 3, 387.

Brain, M. C., Dacie, J. V., and Hourihane, D. O'B. (1962). British fournal of Haematology, 8, 358 .

Brain, M. C., Kuah, K.-B., and Dixon, H. G. (1967). Fournal of Obstetrics and Gynaecology of the British Commonwealth, 74, 702.

Govan, A. D. T. (1961). Pathologia et Microbiologia, 24, 561.

Hawiger, J., Niewiarowski, S., Gurewich, V., and Thomas, D. P. (1970). fournal of Laboratory and Clinical Medicine, 75, 93.

Fournal of Laboratory and Clinical Medicine, 75, 93.
McKay, D. G. (1964). Circulation, 29, Suppl. No. 2, p. 66.

McKay, D. G., and Corey, A. E. (1964). Obstetrics and Gynecology, 23, 508. McKay, D. G., Merrill, S. J., Weiner, A. E., Hertig, A. T., and Read, D. E. (1953). American fournal of Obstetrics and Gynecology, 66, 507

McKay, D. G., and Shapiro, S. S. (1958). Fournal of Experimental Medicine, $107,353$.

Merskey, C., Kleiner, G. J., and Johnson, A. J. (1966). Blood, $28,1$.

Morris, R. H., Vassalli, P., Beller, F. K., and McCluskey, R. T. (1964). Obstetrics and Gynecology, 24, 32

Nilsson, I. M., and Kullander, S. (1967). Acta Obstetrica et Gynecologica Scandinavica, 46, 273.

Pechet, L., and Alexander, B. (1961). New England fournal of Medicine, 265, 1093 .

Talbert, L. M., and Langdell, R. D. (1964). American fournal of Obstetrics and Gynecology, 90, 44

Taub, R. N., Rodríguez-Erdmann, F., and Dameshek, W. (1964). Blood, 24, 775 .

Thomas, D. P., Niewiarowski, S., Meyers, A. R., Bloch, K. J., and Colman, R. W. (1970). New England fournal of Medicine. In press.

Vassalli, P., Morris, R. H., and McCluskey, R. T. (1963). Fournal of Experimental Medicine, 118, 467.

Wardle, E. N., and Menon, I. S. (1969). British Medical Fournal, 2, 625

Woodfield, D. G., Cole, S. K., Allan, A. G. E., and Cash, J. D. (1968) British Medical fournal, 4, 665.

\title{
Cortisol and Growth Hormone Secretion in Relation to Linear Growth: Patients with Still's Disease on Different Therapeutic Regimens
}

\author{
R. A. STURGE,* M.B., B.S. ; C. BEARDWELL, † M.B., B.SC., M.R.C.P. ; M. HARTOG, $\ddagger$ D.M., M.R.C.P.

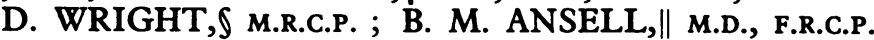

British Medical fournal, 1970, 3, 547-551

\begin{abstract}
Cummary: Linear growth was studied in 20 children suffering from Still's disease on various treatment regimens, and their ability to secrete growth hormone and cortisol was investigated. Growth recovered on reducing daily corticosteroid therapy or on changing to an alternative regimen. Retardation of growth was not due to an absolute inability to secrete growth hormone. Basal plasma cortisol levels and the plasma cortisol response to hypoglycaemia were reduced in patients on daily steroid therapy, but patients on alternate-day prednisone did not differ significantly in this respect from those on non-steroid regimens. Those on alternate-day corticotrophin showed preservation of the circadian rhythm but a subnormal response to hypoglycaemia.
\end{abstract}

\section{Introduction}

Interference with statural growth in children by corticosteroids is well recognized both in those with Cushing's

\footnotetext{
- Senior House Officer, M.R.C. Rheumatism Research Unit, Canadian Red Cross Memorial Hospital, Taplow, Bucks † Medical Registrar, Hammersmith Hospital, London W.12. ₹ Senior Medical Registrar, Hammersmith Hospital, London W.12. f Lecturer in Medicine, Hammersmith Hospital, London W.12. I| Consultant Physician, Canadian Red Cross Hospital, Taplow, Bucks.
}

syndrome (Talbot and Sobel, 1947) and in patients on longterm corticosteroid therapy (Blodgett et al., 1956). Suppression of the hypothalamic-pituitary-adrenal axis also occurs, and to overcome these problems intermittent corticosteroid or corticotrophin regimens have been advocated (Harter et al., 1963; Soyka, 1967; Friedman and Strang, 1966). At the M.R.C. Rheumatism Research Unit maintenance corticosteroid therapy in Still's disease has shown pronounced suppression of growth. For this reason patients have been changed to a regimen of prednisone or corticotrophin on alternate days, while in all cases dosage has been reduced to the lowest possible maintenance level. The present study was undertaken to investigate cortisol and growth hormone release in children with Still's disease on various regimens of steroid treatment and to compare the results with those in similar children who had never received corticosteroids. We have also attempted to correlate the results in the different treatment groups with linear growth.

\section{Method}

Twenty patients suffering from Still's disease and aged from 7.3 to 15.7 years were studied and divided into four groups (Table I). Group 1 had never received corticosteroid 